\title{
Social Representations of the Body among Students of ISSEP Gafsa
}

\author{
Hamdi Tesnime', Chokri Imed', Ben Jannet Zouhaier¹, Elloumi Ali2 \\ ${ }^{1}$ ISSEP Gafsa, Gafsa, Tunisia \\ ${ }^{2}$ Faculté des Lettres et Sciences Humaines de Sfax, Sfax, Tunisia \\ Email: tassou.hamdi@yahoo.fr, chokriimed@gmail.com, ben_jannet2004@yahoo.fr, alielloumi62@gmail.com
}

How to cite this paper: Tesnime, H., Imed, C., Zouhaier, B. J., \& Ali, E. (2016). Social Representations of the Body among Students of ISSEP Gafsa. Creative Education, 7, 2876-2884.

http://dx.doi.org/10.4236/ce.2016.718266

Received: September 24, 2016

Accepted: December 26, 2016

Published: December 29, 2016

Copyright $\odot 2016$ by authors and Scientific Research Publishing Inc. This work is licensed under the Creative Commons Attribution International License (CC BY 4.0).

http://creativecommons.org/licenses/by/4.0/

\begin{abstract}
Our study is based on a quantitative approach in order to gather relevant data. We chose to proceed by means of a pre-established questionnaire with students of the Higher Institute of Sports and Physical Education in Gafsa. We tried to highlight the social representations of the body through the bodily experience, the link of the body to the environment, the social interactions and the notional and normative acquisitions according to gender and the level of study.
\end{abstract}

\section{Keywords}

Body-Social Representations of the Body-Students-Gender-Level of Study

\section{Introduction}

The body is at the centre of numerous research fields and its study is multi-disciplinary. Biology presents a machine body, organised into many levels of integration together with digestion, respiration and locomotion. It is the question of nervous commands, programmes, reflexes, techniques, mastery, and an organic body. But, what about the subject body, that of emotions, desires, sensations, pleasure?

Christine Detrez (2002) evokes that the body is a gift (more or less gracious) of nature, whether these are thought on the mode of divinity or biology. The common evidence is anyway there to strengthen: the individual is incarnated throughout his life, from the first cry till the latest breath, in a particular body. Whatever were the eventual modifications we bring to it, from make-up to the colour of the hair, grafts to change the gender, the material of departure is given at birth. It is also by nature that features and social positions, and the relation cause-effect justify the established, legitimate order in some sort of social order, suggesting, as underlined by David le Breton "that the 
biological features of the man make only his position on the whole which comes back to him by rights. Instead of making corporality an effect of the social condition of the man, this thought makes of the social condition the direct product of his body (...). The destiny of the man is subscribed immediately in the morphological conformation". $\mathrm{He}$ concludes: "finally, the order of the world responds to a biological order to which it is enough to search proofs in the manifestations of the body" (Le Breton, 1993: p. 16).

Talking about the social construction of the body also breaks with the anthological experience both individual and common which contributes to suggesting the body as natural expression of the individual. The body would deliver the individual in their nudity, in this state of "nature" which is sometimes decried to the name of supremacy of the soul, reason, culture, which would distinguish each in their turn the man from the animal, or sometimes lauded, researched through Rousseau's myths of the noble savage or more contemporary exhortations to find their sensations and listen to their body. In a case as in the other, the body and the barrier constituted by the skin would also be the concrete demarcation between the innate and the acquired, nature and culture, the individual and the society. Against this evidence, the hypothesis of the body as a social construction implies to think of the body as an object, the stake and the product of socialization, which would also make the body as well a place of representation and reproduction not only of individuals but also of gendered and social identities. The body also involves polymorph socialization; it is all more difficult to understand that it is often diffuse, winning with "the evidence of the natural and the natural of the evidence" (Blöss, 2001).

The social representation of the body allows the subject to give a meaning to his practice, to analyse the reality of the body dimensions of the user. There is a direct link between the social representation and the practice followed, an inter-relation between the two aspects. Jean-Claude Abric (2001: p. 18) considers that "by those functions of elaboration of a common sense, construction of the social identity, by the expectations and the anticipations it generates, representation is responsible for the social practices".

Denise Jodelet defines the social representation as "a knowledge form socially elaborated and shared, having a practical target and contributing to the construction of a reality common to a social group". The representations are "organised under the species of knowledge saying something about the state of reality" (Jodelet, 2003: p. 53).

They constitute "modalities of practical thinking oriented towards communication, comprehension and the mastery of the social environment, both material and ideational" (Jodelet, 2003: p. 365).

From those elements of definition, we will study what constitutes the social representations of the body among the Tunisian population, particularly in the South (Gafsa), and how they are generally built, then, specifically applied on our object, the social representations of the body among the students of the Higher Institute of Sports and Physical Education of Gafsa, Tunisia.

We are not interested in the atomic, physiological body here; rather we are interested in the experienced body, professionally invested in the sporting and physical activity, all at once mediator and tool, author of actions and carrier of meaning. What are the links 
we can weave between social representations of the body, gender, and the level of study? How do the diverse notions of the social representations articulate to apprehend the body as a social construct? A body of education? A body health? A body fun? A body performance? Or let us say what are the social representations of the body among students of ISSEP Gafsa?

\section{Materials and Methods}

Our intention is to study the link of the body which can make the object of the social representations of the body of the students of ISSEP Gafsa with taking into consideration of both genders and the level of study.

1) The lived body of the students of ISSEP Gafsa depends on gender and the level of study.

2) The link of the body to the social environment depends on the gender of the subjects studied and the level of study.

3) The social interactions take into consideration the presence of men and women, and the level of study.

4) Students forge of the social representations of the body through the notional and normative acquisitions that are influenced by gender and the level of study.

\subsection{Study Population}

We arbitrarily chose students (their characteristics are mentioned in Table 1) of the Higher Institute of Sports and Physical Education in terms of gender and level of study. Most of them belong to South Tunisia.

\subsection{Investigation Tool}

From an elaborated questionnaire, we opted for the analysis of reliability (Cronbach Alpha which is equal to $70 \%$ ). We also tried to study the social representations of the body of the students of ISSEP Gafsa (south Tunisia) through items (65 items) in the form of a scale from 1 to 4 (1: absolutely; 2: yes; 3: more or less; 4: no).

The questionnaire consists of different parts:

i) General characteristics.

ii) The social representations of the body.

a) The bodily experience.

Table 1. Characteristics of the study population.

\begin{tabular}{|c|c|c|c|c|c|c|}
\hline & \multicolumn{2}{|c|}{$1^{\text {st }}$ year } & \multicolumn{2}{|c|}{$2^{\text {nd }}$ year } & \multicolumn{2}{|c|}{$3^{\text {rd }}$ year } \\
\hline & Number & Age & Number & Age & Number & Age \\
\hline Woman & 25 & $\begin{array}{c}\text { Varies } \\
\text { from } 19 \text { to } 24\end{array}$ & 25 & $\begin{array}{c}\text { Varies } \\
\text { from } 20 \text { to } 25\end{array}$ & 25 & $\begin{array}{c}\text { Varies } \\
\text { from } 21 \text { to } 26\end{array}$ \\
\hline Man & 25 & $\begin{array}{c}\text { Varies } \\
\text { from } 19 \text { to } 25\end{array}$ & 25 & $\begin{array}{c}\text { Varies } \\
\text { from } 20 \text { to } 26\end{array}$ & 25 & $\begin{array}{c}\text { Varies } \\
\text { from } 21 \text { to } 27\end{array}$ \\
\hline
\end{tabular}


b) The link of the body to the environment.

c) The social interactions.

d) Notional and normative acquisitions.

\subsection{Statistical Analysis}

Through the statistical analysis of KHI two of Pearson, we could raise the asymptotic significations and we elaborated cross tabulations in terms of items, level of study and gender.

\section{Results}

\subsection{Verification of Hypothesis No. 1: The Bodily Experience}

Table 2 shows the influence of the sporting experience of the students and the access to sporting practice in terms of gender and the level of study allows us to deduce that sports is a purely masculine field. Since masculine students are more invested in sport clubs and civil clubs. This can be confirmed by the sporting practice of the family members of the masculine gender (fathers, brothers) in spite of women. Whereas the level of study has no effect on the sporting practice of the students of ISSEP Gafsa.

Through Table 3, statistical analysis of Khitwo reveals a significant difference to $p=$ 0.01 in favour of men (68\%). They consider body as a machine to perform.

\subsection{Verification of Hypothesis No. 2: The Link of the Body} to the Social Environment

\section{a) According to gender}

Table 4 shows that masculinity of the sporting domain can explain the significant

Table 2. Sporting practice according to gender and the level of study.

\begin{tabular}{ccccc}
\hline & & $\mathbf{1}^{\text {st }}$ year & $\mathbf{2}^{\text {nd }}$ year & $\mathbf{3}^{\text {rd }}$ year \\
\hline University sport & Woman & 18 & 24 & 23 \\
& Man & 20 & 20 & 17 \\
Sport clubs & Woman & 9 & 14 & 16 \\
& Man & 20 & 20 & 16 \\
Civil club & Woman & 11 & 8 & 12 \\
& Man & 16 & 17 & 12 \\
Past-time & Woman & 13 & 3 & 9 \\
& Man & 13 & 11 & 17 \\
\hline
\end{tabular}

Table 3. According to gender; body machine to perform.

The body is machine to perform

\begin{tabular}{cc}
\hline & The body is machine to perform \\
\hline Woman & $58.66 \% p=0.01$ \\
Man & $68 \% p=0.01$ \\
\hline
\end{tabular}


and quite significant differences ( $p$ varies between $p=0.02$ and $p=0.005$ ) in favour of men. In the sporting practice, men try to prove their masculinity and their virility through the engagement and the overrun of physical limits in diverse intense physical activities. Whereas women consider that the investment of the body in the sporting practice is marked by the endurance to pain and easing discomfort.

The image of the body allows the individual to give a meaning to his practice, and to seize their conducts and attitude well against his body and the bodies of others and in terms of social context. Abric considers that "by its functions of elaboration of a common sense, the construction of a social identity, by the expectations and the anticipations it generates, the representation is behind the social practices".

\section{b) According to the level of study}

The statistical analysis of the questions related to the investment of the body in the sporting practice reveals through Table 5 quite significant differences $(p=0.001 \& p=$ $0.01)$ and significant differences $(p=0.02 \& p=0.04)$. Indeed, first year students give more importance for performative efficacy in high-intensity activities. They consider the bodily existence as a performing body, this is explained by the study regime which gives more importance to the sporting practice.

Whereas most of the second year students (84\%) preview that the investment of the body in the sporting field is endurance to pain and easing to discomfort due to the study regime which is loaded of physical activities.

Final year students choose the biological body as the body is related to everything that is teaching and pedagogical attitude (preparation of the body for the activity and everything pedagogical).

\subsection{Verification of Hypothesis No. 3: Social Interactions}

\section{a) According to gender}

Concerning the bodily appearance in the social loo in terms of gender, the statistical analysis shows in Table 6 a significant difference $(p=0.04)$ concerning women who feel good in their body and prefer the company of the opposite sex $(p=0.007)$.

The report to the body is not only limited to the social representations of the bodily practices but also to the report between both genders and the social status of each one.

Indeed, the link to the body is different among both genders due to the beliefs and perceptions of the body. Men conceive their body as object of belonging to the other and want to change their body to a muscular body, object of masculinity and virility.

The use of bodily appearance depends on the social context where the individual evolves. The mastery of this socio-bodily knowledge constitutes an issue of belonging to the social group. The bodily appearance is a social construct in which the practices of the actors are in action.

\section{b) According to the level of study}

The notion of the social representation of the body differs according to the level of study through Table 7.

-First year students of ISSEP Gafsa conceive their body as source of physical well- 
being for $80 \%(p=0.002)$ of performative efficacy for $76 \%(p=0.008)$ and belonging to the self, family and society.

-Second year students consider their body as object of belonging to others $(92 \%, p=$

Table 4. Investment of the body in the sporting practice according to gender.

\begin{tabular}{|c|c|c|c|c|c|c|}
\hline & $\begin{array}{l}\text { Exceed the } \\
\text { sporting limits }\end{array}$ & $\begin{array}{c}\text { Performative efficacy } \\
\text { and identity }\end{array}$ & $\begin{array}{l}\text { Body of } \\
\text { rugbymen }\end{array}$ & $\begin{array}{l}\text { Slender bodies } \\
\text { of swimmers }\end{array}$ & $\begin{array}{l}\text { Endurance } \\
\text { to pain }\end{array}$ & $\begin{array}{c}\text { Easing } \\
\text { discomfort }\end{array}$ \\
\hline Woman & $\begin{array}{c}24 \% \\
p=0.01\end{array}$ & $\begin{array}{c}48 \% \\
p=0.005\end{array}$ & $\begin{array}{l}25.33 \% \\
p=0.02\end{array}$ & $\begin{array}{l}54.66 \% \\
p=0.01\end{array}$ & $\begin{array}{c}78.66 \% \\
p=0.02\end{array}$ & $\begin{array}{c}86.66 \% \\
p=0.01\end{array}$ \\
\hline Man & $\begin{array}{c}40 \% \\
p=0.01\end{array}$ & $\begin{array}{c}73.33 \% \\
p=0.005\end{array}$ & $\begin{array}{c}44 \% \\
p=0.02\end{array}$ & $\begin{array}{l}73.33 \% \\
p=0.01\end{array}$ & $\begin{array}{c}72 \% \\
p=0.02\end{array}$ & $\begin{array}{l}66.66 \% \\
p=0.01\end{array}$ \\
\hline
\end{tabular}

Table 5. Investment of the body in the sporting practice according to the level of study.

\begin{tabular}{|c|c|c|c|c|c|c|c|c|c|}
\hline & $\begin{array}{c}\text { Performative efficacy } \\
\text { and identity }\end{array}$ & $\begin{array}{l}\text { Bodies of } \\
\text { rugbymen }\end{array}$ & $\begin{array}{l}\text { Bodies of } \\
\text { runners }\end{array}$ & $\begin{array}{l}\text { Bodies of } \\
\text { boxers }\end{array}$ & $\begin{array}{l}\text { Endurance } \\
\text { to pain }\end{array}$ & $\begin{array}{c}\text { Easing } \\
\text { discomfort }\end{array}$ & $\begin{array}{l}\text { Biological } \\
\text { body }\end{array}$ & $\begin{array}{c}\text { Performing } \\
\text { body }\end{array}$ & $\begin{array}{l}\text { Masculine } \\
\text { bodily habits }\end{array}$ \\
\hline $1^{\text {st }}$ year & $\begin{array}{c}72 \% \\
p=0.01\end{array}$ & $\begin{array}{c}48 \% \\
p=0.001\end{array}$ & $\begin{array}{c}72 \% \\
p=0.02\end{array}$ & $\begin{array}{c}60 \% \\
p=0.02\end{array}$ & $\begin{array}{c}70 \% \\
p=0.04\end{array}$ & $\begin{array}{c}78 \% \\
p=0.008\end{array}$ & $\begin{array}{c}74 \% \\
p=0.01\end{array}$ & $\begin{array}{c}80 \% \\
p=0.02\end{array}$ & $\begin{array}{c}74 \% \\
p=0.02\end{array}$ \\
\hline $2^{\text {nd }}$ year & $\begin{array}{c}56 \% \\
p=0.01\end{array}$ & $\begin{array}{c}26 \% \\
p=0.001\end{array}$ & $\begin{array}{c}42 \% \\
p=0.02\end{array}$ & $\begin{array}{c}32 \% \\
p=0.02\end{array}$ & $\begin{array}{c}84 \% \\
p=0.04\end{array}$ & $\begin{array}{c}84 \% \\
p=0.008\end{array}$ & $\begin{array}{c}54 \% \\
p=0.01\end{array}$ & $\begin{array}{c}58 \% \\
p=0.02\end{array}$ & $\begin{array}{c}52 \% \\
p=0.02\end{array}$ \\
\hline $3^{\text {rd }}$ year & $\begin{array}{c}54 \% \\
p=0.01\end{array}$ & $\begin{array}{c}30 \% \\
p=0.001\end{array}$ & $\begin{array}{c}52 \% \\
p=0.02\end{array}$ & $\begin{array}{c}48 \% \\
p=0.02\end{array}$ & $\begin{array}{c}72 \% \\
p=0.04\end{array}$ & $\begin{array}{c}68 \% \\
p=0.008\end{array}$ & $\begin{array}{c}76 \% \\
p=0.01\end{array}$ & $\begin{array}{c}56 \% \\
p=0.02\end{array}$ & $\begin{array}{c}60 \% \\
p=0.02\end{array}$ \\
\hline
\end{tabular}

Table 6. Bodily appearance in the social look in terms of gender.

\begin{tabular}{|c|c|c|c|c|c|c|c|c|}
\hline & $\begin{array}{l}\text { Good in } \\
\text { their body }\end{array}$ & $\begin{array}{c}\text { Change of the } \\
\text { bodily } \\
\text { appearance }\end{array}$ & $\begin{array}{l}\text { Change towards a } \\
\text { muscular body }\end{array}$ & $\begin{array}{c}\text { The body } \\
\text { belongs to } \\
\text { me }\end{array}$ & $\begin{array}{l}\text { The body } \\
\text { does not } \\
\text { belong to me }\end{array}$ & $\begin{array}{l}\text { The body limits } \\
\text { the personal } \\
\text { liberty }\end{array}$ & $\begin{array}{l}\text { Comfortable with } \\
\text { the other sex }\end{array}$ & $\begin{array}{l}\text { Sport uniform } \\
\text { in front of } \\
\text { others }\end{array}$ \\
\hline Man & $\begin{array}{c}73.33 \% \\
p=0.04\end{array}$ & $\begin{array}{c}53.33 \% \\
p=0.002\end{array}$ & $\begin{array}{c}66.66 \% \\
p=0.001\end{array}$ & $\begin{array}{c}70 \% \\
p=0.001\end{array}$ & $\begin{array}{c}41.33 \% \\
p=0.02\end{array}$ & $\begin{array}{c}57.33 \% \\
p=0.001\end{array}$ & $\begin{array}{c}58.66 \% \\
p=0.007\end{array}$ & $\begin{array}{c}42.66 \% \\
p=0.001\end{array}$ \\
\hline
\end{tabular}

Table 7. Bodily appearance in the social respect in terms of the level of study.

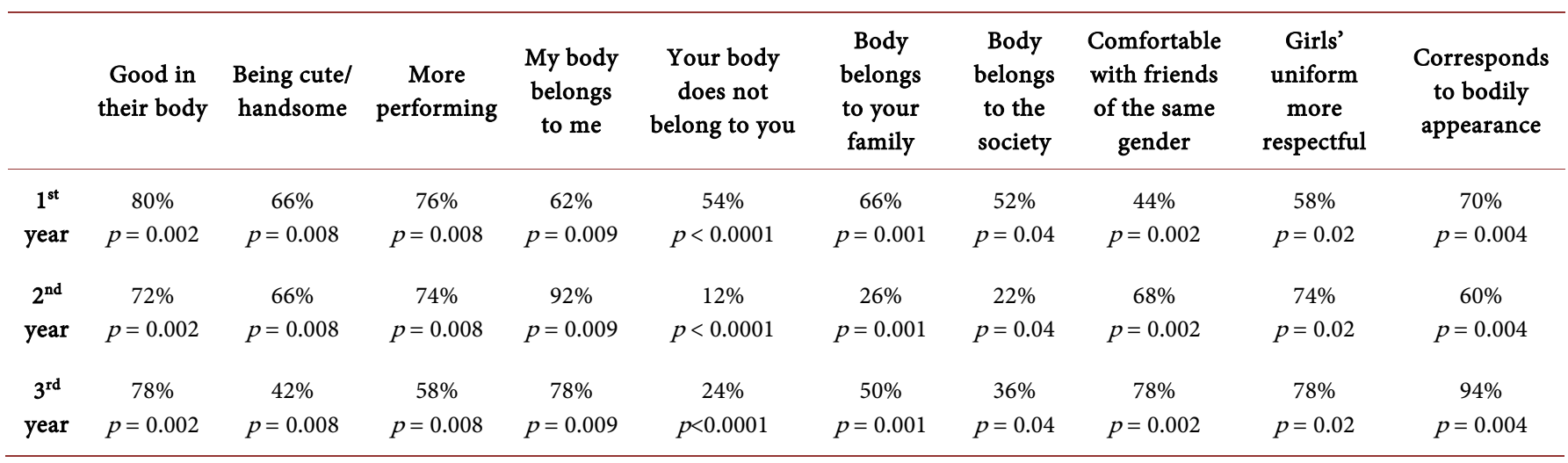


$0.009)$ and feel comfortable with friends of the same gender with $78 \%(p=0.002)$.

-Final year students postulate that the sport uniform for girls must be respectful (78\%, $p=0.02)$ which correspond to bodily appearance $(94 \%, p=0.004)$.

\subsection{Verification of the Hypothesis No. 4: Notional and Normative Acquisitions}

\section{a) According to gender}

We did not raise a significant difference in Table 8 for the influence of gender on the notional and normative acquisitions for the representations of the body of men only, which is distinguished by power and muscle structure in favour of women for $p=0.01$ which is a very significant difference.

\section{b) According to the level of study}

Table 9 shows notional and normative acquisitions according to the level of study:

$-80 \%$ of the $3^{\text {rd }}$ year students assume that the body of the man stands for power and muscle structure.

$-66 \%$ of the $1^{\text {st }}$ year students and $66 \%$ of the $3^{\text {rd }}$ year students consider the body as object of medical sciences.

$-66 \%$ of the $1^{\text {st }}$ year students conceive the body as object of cosmetic products.

\section{Discussion}

The sports experience of students in terms of gender and level of study allows to deduce that sports is a purely masculine domain. Men consider the body as a machine to perform.

For the link between the body and the social environment, men prove their masculinity and virility through overtaking the physical limits. Women consider that the investment of the body in the physical activity is guaranteed with endurance and easing discomfort.

Feminity and masculinity, depicted through corporeity, are expressed with specific bodily forms, postures and attitudes, style and gestures, as well as differentiated usages

Table 8. Bodily practices in term of gender.

\begin{tabular}{cc}
\hline & The body of the man is distinct by power and musculature \\
\hline Woman & $73.33 \% p=0.01$ \\
Man & $48 \% p=0.01$
\end{tabular}

Table 9. Bodily practices in terms of the level of study.

\begin{tabular}{cccc}
\hline & $\begin{array}{c}\text { Body of the man is distinguished by } \\
\text { power and musculature }\end{array}$ & $\begin{array}{c}\text { Body object for } \\
\text { medical sciences }\end{array}$ & $\begin{array}{c}\text { Body object for } \\
\text { cosmetic products }\end{array}$ \\
\hline $1^{\text {st }}$ year & $68 \% p<0.0001$ & $66 \% p=0.009$ & $66 \% p=0.001$ \\
$2^{\text {nd }}$ year & $34 \% p<0.0001$ & $32 \% p=0.009$ & $26 \% p=0.001$ \\
$3^{\text {rd }}$ year & $80 \% p<0.0001$ & $66 \% p=0.009$ & $46 \% p=0.001$ \\
\hline
\end{tabular}


of the body. By integrating the body itself, its gender properties the enclose the individual and their body appearance in such behavioural models and prototypes of selfpresentation stereotyped according to the group of gender of belonging.

Thereby, feminity and masculinity are expressed by the distinguished criteria that found it and define the boundaries of the models of feminine and masculine body. They are socially constructed and this construction "pushes us to believe in its necessity and naturality" (Butler, 2006: p. 264), but also in its aspect of unchangeable appearance.

Concerning the level of study, first year students give more importance to the so-called performative efficacy. Although most the second-year students preview that the bodily investment in the activity is an endurance to pain and easing discomfort, final-year students choose the biological body.

For the social interactions, women feel better with their body and prefer the company of the opposite gender. Men conceive their body as object of belonging to others and want to change their body to a musculated one.

First-year students conceive their body as a source of physical well being. For the second-year students, they consider their body as an object of belonging to others. Third-year students assume that the sports uniform of girls must be more respectful.

The model of the sporting body returns obviously to the strong, musculated efficient competitive body in which the appreciation depends on the masculine norms. Masculinity constitutes, indeed, the framework in the sporting, considering the completely physical aspect of this practice (Bryson, 1990).

The representation of men's body, according to the notional and normative acquisitions is distinguished by force and musculature. For the level of study, the third-year students assume that men's body is distinguished by force and musculature. Second-year students consider the body as an object of medical sciences and cosmetic products.

Usages of the body for both genders are codified and legitimated with reference to a body model, sporting body, which is distinguished with prescriptive values and specific body norms (Lachheb, 2007).

\section{Conclusion}

Concerning the bodily experience, male students are invested in the sporting field and consider body as a machine to perform. For the link of the body to the social environment, we have significant and even quite significant differences in favour of men since they try to prove their masculinity in diverse activities. The level of study relieves quite significant and significant differences for $1^{\text {st }}$ year students. However, the bodily appearance in the social regard in terms of gender shows a significant difference for women who feel good in their body. The notion of social representation of the body differs according to the level of study. Finally, for the notional and normative acquisitions in terms of gender, we did not relieve significant differences. However, the level of study shows more differences between the students of all levels. 


\section{References}

Abric, J. C. (2001). Social Practices and Representations (p. 18). Paris: PUF.

Blöss, T. (2001). The Dialectic of Relationships between Men and Women. Paris: PUF.

Bryson, L. (1990). Challenges to Male Hegemony in Sport. In M. Messner, \& D. Sabo (Dir.), Sport, Men and the Gender Order: Critical Feminist Perspectives (pp. 173-184). Illinois: Human Kinetics.

Butler, J. (2006). Gender Troubles. Feminism and the Subversion of Identity. Paris: The Discovery.

Detrez, C. (2002). The Social Construction of the Body. Paris: Threshold Editions.

Jodelet, D. (2003). Social Representations (p. 53, 365). Paris: PUF.

Lachheb, M. (2007). Models of the Body and Pedagogical Models through Contemporary Tunisian Physical Education. Doctoral Thesis in Sociology. Montpellier: University of Montpellier III.

Le Breton, D. (1993). The Living Flesh, Medical and Social Uses of the Human Body. Paris: Métailié.

Submit or recommend next manuscript to SCIRP and we will provide best service for you:

Accepting pre-submission inquiries through Email, Facebook, LinkedIn, Twitter, etc.

A wide selection of journals (inclusive of 9 subjects, more than 200 journals)

Providing 24-hour high-quality service

User-friendly online submission system

Fair and swift peer-review system

Efficient typesetting and proofreading procedure

Display of the result of downloads and visits, as well as the number of cited articles

Maximum dissemination of your research work

Submit your manuscript at: http://papersubmission.scirp.org/

Or contact ce@scirp.org 